\title{
DISTRIBUTION OF WOODY VEGETATION ON SODA WASTE DUMPS IN RELATION TO SPATIAL VARIATION IN SELECTED PARAMETERS OF THE MINERAL COVER
}

\author{
Ewelina Zając', Sławomir Klatka', Jan Zarzycki²
}

1 Department of Land Reclamation and Environmental Development, University of Agriculture in Krakow, Al. Mickiewicza 24-28, 30-059 Kraków, Poland, e-mail: e.zajac@ur.krakow.pl

2 Department of Ecology, Climatology and Air Protection, University of Agriculture in Krakow, Al. Mickiewicza 24-28, 30-059 Kraków, Poland

Received: 2016.08.11 Accepted: 2016.09 .26 Published: 2016.11.01

\begin{abstract}
Development of woody plants in the course of succession on reclaimed soda waste dumps by use of mineral cover was analyzed. The spatial variation in the thickness and granulometric composition of the mineral cover was analysed by the Kriging method. The statistical measurements and geostatistical analysis were used to create maps showing areal variability for the parameters analysed. Analysis of the development of woody vegetation was based on field work and raster layers created on the basis of aerial photographs. No link was found between the parameters of the mineral cover and the distribution and development of spontaneous woody vegetation. The species composition in the study area is limited, and dominated by pioneer species, mainly the expansive black locust (Robinia pseudoacacia). Given that the soda waste disposal site is to be used as urban green spaces, the target ecosystem structure must be considered and a suitable course of action selected: further reclamation procedures improving substrate quality and enrichment of the species composition of the tree stand, or management involving sustaining the current state while controlling the course of natural succession of vegetation.
\end{abstract}

Keywords: soda waste dumps, succession, woody species, reclamation, Krakow Soda Plant Solvay

\section{INTRODUCTION}

The soda waste disposal site of the former Krakow Soda Plant Solvay (KSP), known as the 'White Seas', covers an area of nearly 85 ha. Settling ponds, accumulating hydraulically transported waste arising from the production of crude and caustic soda and soda ash, were exploited from the 1930s until the end of 1990. They were built as multi-chamber aboveground ponds, grouped in three complexes (Figure 1). The outer embankments, with an average inclination of 1:1.5 and a maximum height of 24.0-27.5 $\mathrm{m}$ above ground level (soda waste ponds nos. 21-25), were made of waste materials such as slag, combustion waste, and limestone waste. The chemical com- position of the waste deposited in the soda waste dumps consisted mainly of calcium carbonate $\left(\mathrm{CaCO}_{3}\right)$ with an admixture of calcium sulphate $\left(\mathrm{CaSO}_{4}\right)$ and silicon dioxide $\left(\mathrm{SiO}_{2}\right)$ in the form of a suspension in a solution of calcium chloride $\left(\mathrm{CaCl}_{2}\right)$ and water [Pałka and Sanecki 1992, Boroń et. al. 2000].

The functioning of the waste disposal site, which lasted several decades, was associated with numerous nuisances, including highly saline effluent and airborne dust from the drying waste. The primary means of reclamation of areas creating this type of problem is the formation of permanent vegetation cover on their surface [Siuta 2014]. Reclamation works were carried out on the soda waste dumps of the former KSP in the 
years 1989-1995. In the largest complex of ponds they covered an area of 17.43 ha. The reclamation involved levelling of the embankments separating individual sludge ponds, reinforcement of the slopes, application of a layer of mineral soil, levelling of the terrain, application of mineral fertilizers, and sowing of a mixture of grasses and leguminous plants [Małecki 1997].

The potential for management of this attractive location as an urban green area, surrounded by intensive residential development, was perceived early on, and work on the creation of an effective method for reclamation of the soda waste dumps was already begun during the final phase of operation of the KSP [Boron et al. 2000]. Over the years studies have been conducted on the process of natural succession and development of vegetation on both unreclaimed and reclaimed soda waste dumps [e.g. Trzcińska-Tacik 1966, 1993, Zarzycki and Zając 2001, Zając and Zarzycki 2012], including experiments on the possibility of management involving appropriately selected plant species [Nagawiecka et al. 1975-1977]. The literature also describes studies dealing with various aspects of the biological reclamation of other soda waste dumps, e.g. Urbańska and Urbański 2012, Siuta 2014, Dyguś and Sienkiewicz 2014, Siuta and Sienkiewicz 2001, 2014.

According to the current urban management plan for the 'White Seas' [Uchwała nr LVIII/777/12], the complex of reclaimed soda waste dumps of the KSP is to be used as green urban spaces and for sport and recreational facilities. In this context research dealing with the effect of the reclamation procedures on the development of vegetation takes on particular importance. The aim of the present study was to determine the distribution of woody vegetation on a reclaimed complex of soda waste dumps from the former KSP in relation to spatial variation in basic parameters (thickness and granulometric composition) of the mineral cover applied.

\section{MATERIALS AND METHODS}

The properties of the mineral soil used in reclamation of soda waste ponds nos. 21-25 (Figure 1) (50 $00^{\prime} 33^{\prime \prime} \mathrm{N}$; 19 $\left.9^{\circ} 56^{\prime} 26^{\prime \prime}\right)$ were surveyed in 2007. Altogether 132 plots were laid out by GPS in a $30 \times 30 \mathrm{~m}$ grid. On each plot the thickness of the mineral cover was measured with a soil probe and material was collected for labora-

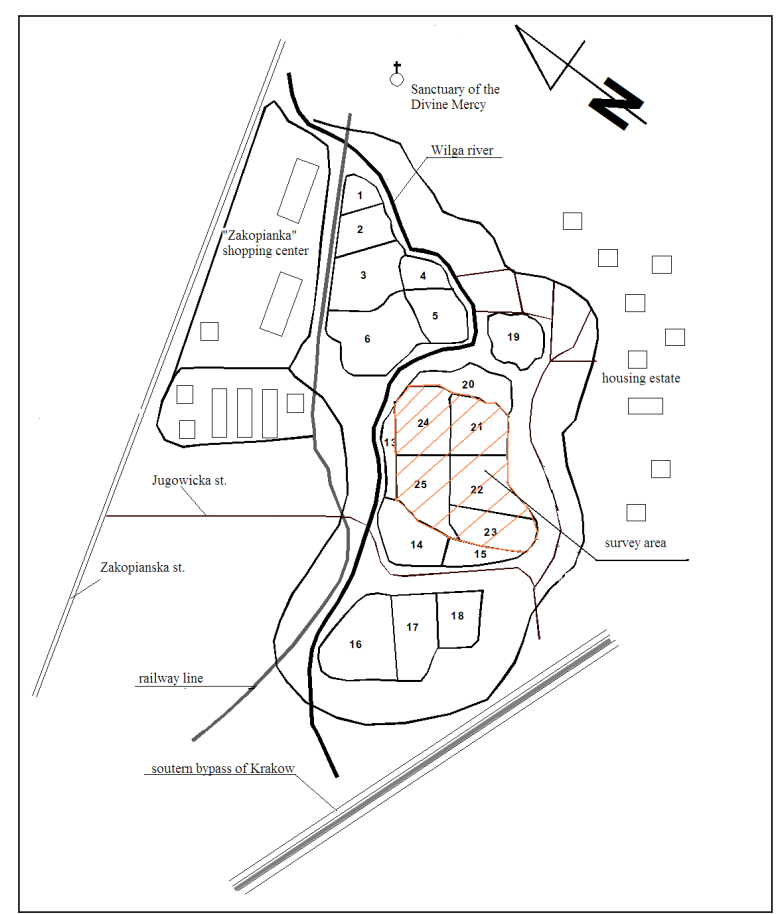

Figure 1. Diagram of the location of the soda waste dumps of the former KSP in Krakow as of 2007

tory analyses (pooled samples). The granulometric composition was determined by the areometer method (BN - 78/9180-11).

In order to characterize the parameters analysed and determine their degree of variation, the following statistical measures were calculated [Hellwig 1993]: maximum value, minimum value, mean, variance, standard deviation, and coefficient of variation. The coefficient of variation was determined as a measure of the spread of variance and standard deviation and expressed as a percentage. Spatial variation was presented graphically by assigning position vectors to each measuring point $(x, y)$ in the grid. Analysis of the data in each column of the grid showed a linear relationship between the means from individual columns and their variance, which suggests a trend - the existence of systematic variation. Therefore Kriging was used for analysis of spatial variation and interpolation of maps [Marx and Thompson 1987]. Maps of spatial variation were plotted using Surfer for Windows software.

The input data for analysis of the development of woody vegetation was based on raster layers created in MapInfo Professional 11.5 software using aerial photographs taken in 2003 and 2015 and obtained from the Main Geodetic and Cartographic Documentation Centre. Moreover, in 2015 a general inventory of the main patches (disregarding single trees) of the spontaneous 
woody vegetation was performed. In each patch trees with a trunk diameter of over $7 \mathrm{~cm}$ at a height of $130 \mathrm{~cm}$ were counted. The number of trees and the maximum heights and diameters were determined for the species distinguished. The heights of the trees were measured with a clinometer.

\section{RESULTS AND DISCUSSION}

The results of the tests of the mineral cover used for reclamation of soda waste dumps nos. 21-25 are described in detail in works by Zając [2009], Zając and Zarzycki [2012]. It should be emphasized that the granulometric composition was analysed before the Polish Society of Soil Science adopted its 2008 resolution on classification of particle size distribution and textural classes of soil and mineral materials [Klasyfikacja... 2008], which explains the diameter ranges of the granulometric fractions.

The mineral cover had a mean thickness of $0.25 \mathrm{~m}$, exceeding $0.5 \mathrm{~m}$ on only five of the research plots $(\max 0,68 \mathrm{~m})$. The soil used for reclamation was loam. Heavy loam was clearly dominant, present on $76 \%$ of the research plots. According to the Polish Society of Soil Science classification [Klasyfikacja... 2008], this material qualifies as clay loam and belongs to the agrotech- nical category of heavy soils (fine-textured soils). The mean content of the sand fraction was $29.70 \%$, the silt fraction was $13.27 \%$, and the clay fraction was $57.33 \%$ (Table 1). The coefficient of variation indicates that thickness was the most spatially varied parameter in the study area ( $\vartheta=44,25 \%$ ). Among the granulometric fractions, sand $(\vartheta=$ $32,57 \%$ ) and silt ( $\vartheta=28,81 \%$ ) exhibited intermediate variation, while the clay fraction showed little variation ( $\vartheta=18,36 \%$ ). The results are similar to those obtained in a study by Klatka et al. [2005] and Klatka [2009] on other reclaimed soda waste dumps (no. $17 \mathrm{i} 18$ ) of the KSP.

The maps of spatial variation in the parameters analysed by the Kriging method (Figures 2-5), taking into account all of the measurement plots, confirm the results obtained in the preliminary statistical analysis (coefficient of variation) and can be used for further estimation of additional points, enabling more precise determination of mineral cover characteristics.

Woody vegetation covering the soda waste dumps shows little species diversity. Seven tree species were counted, and the presence of three of these, i.e. white poplar (Populus alba), English walnut (Juglans regia) and bird cherry ( $\mathrm{Pa}$ dus avium), was noted only twice in the case of each species. The most abundant was black locust

Table 1. Statistical measures of the analysed mineral cover parameters

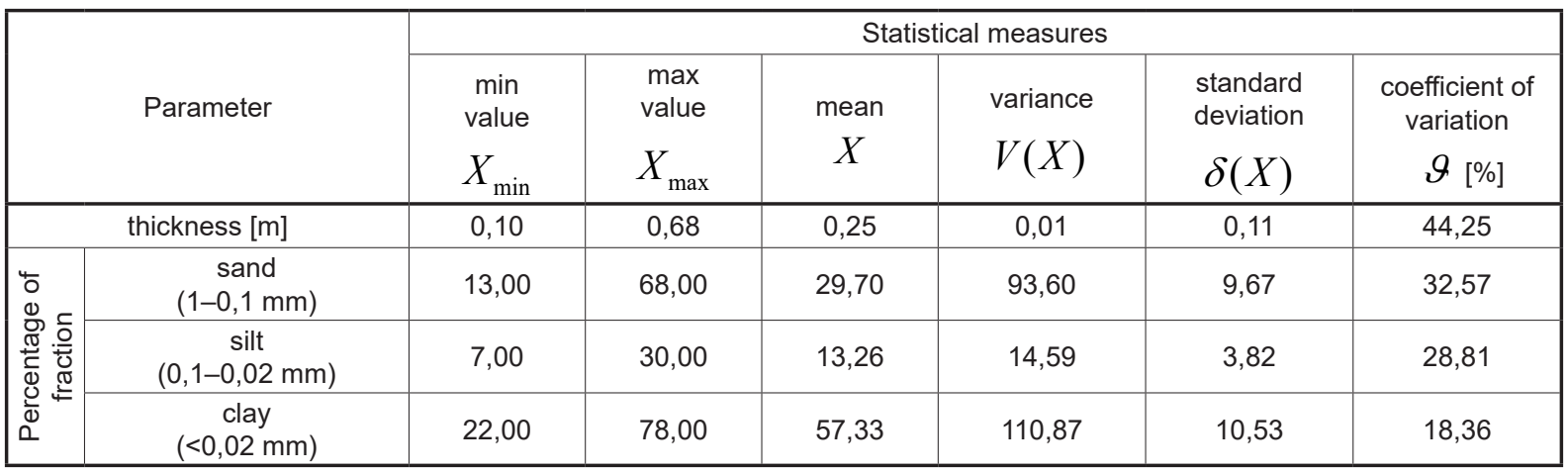

Table 2. General characteristics of the main tree species in the inventoried area

\begin{tabular}{|c|c|c|c|c|c|}
\hline & & $\begin{array}{c}\text { Black locust } \\
\text { (Robinia pseudoacacia) }\end{array}$ & $\begin{array}{l}\text { European aspen } \\
\text { (Populus tremula) }\end{array}$ & $\begin{array}{c}\text { Silver birch } \\
\text { (Betula pendula) }\end{array}$ & $\begin{array}{l}\text { Goat willow } \\
\text { (Salix caprea) }\end{array}$ \\
\hline \multicolumn{2}{|c|}{ Number / \% } & $1204 / 84$ & $143 / 10$ & $70 / 5$ & $22 / 1$ \\
\hline \multirow{3}{*}{ 蒿它 } & $\min$ & 10 & 6 & 7 & 5 \\
\hline & $\max$ & 20 & 20 & 18,5 & 11 \\
\hline & mean & 13,9 & 12,2 & 12,6 & 8,2 \\
\hline \multirow{3}{*}{ 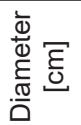 } & $\min$ & 9 & 7 & 9 & 10 \\
\hline & $\max$ & 33 & 44 & 28 & 20 \\
\hline & mean & 21,1 & 19,9 & 18,1 & 14,4 \\
\hline
\end{tabular}




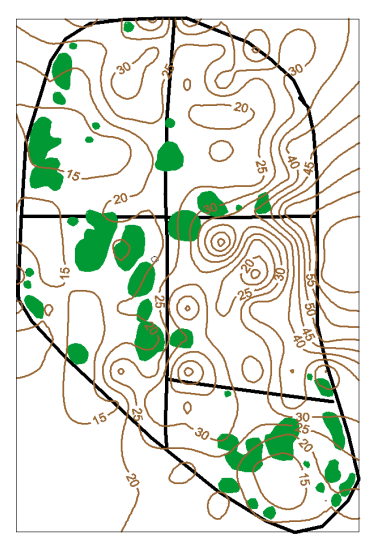

2003

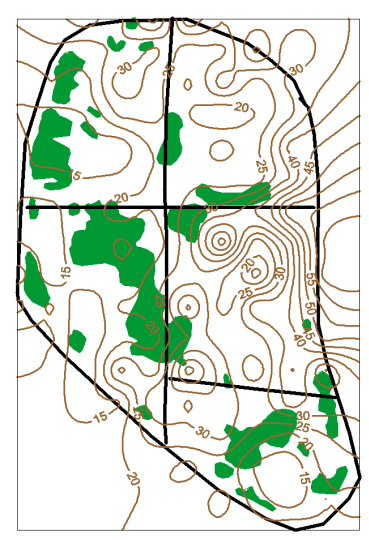

2015

Figure 2. Distribution of the main clusters of trees in relation to spatial variation in the thickness of the mineral cover

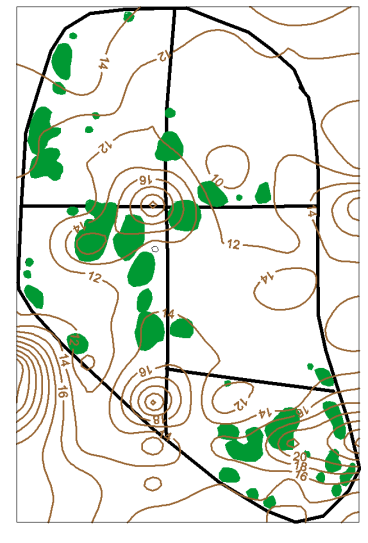

2003

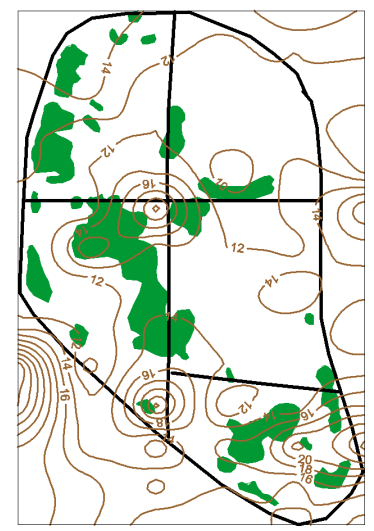

2015

Figure 4. Distribution of the main clusters of trees in relation to spatial variation in the silt fraction

(Robinia pseudoacacia), with somewhat lower numbers of European aspen (Populus tremula), silver birch (Betula pendula), and goat willow (Salix caprea) (Table 2).

Black locust accounted for as much as $84 \%$ of the tree species composition. It attained an average height of $13.9 \mathrm{~m}$ and a diameter at breast height of $21.1 \mathrm{~cm}$ (Table 2). This tree comes from North America and is one of the three most widely distributed alien species in Europe. It is a heliophyte and fast-growing pioneer species. It grows on abandoned and degraded land, tolerating soils of different degrees of fertility, including poor and dry soils, but does not tolerate wet or compacted soils. Black locust reproduces both generatively and vegetatively, forming strong root suckers. The production of more numerous root suckers is stimulated by factors such as mechanical damage or fire [Ciejracks et al. 2013]. On the soda waste dumps the black locust trees often had a deformed

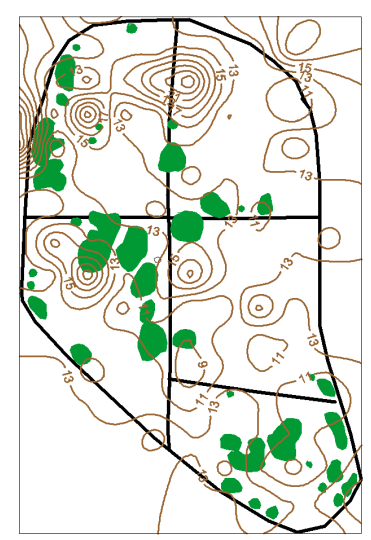

2003

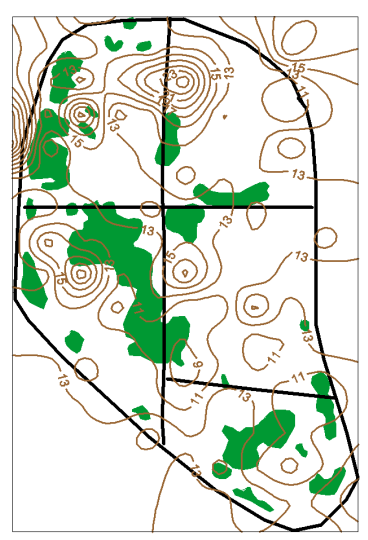

2015
Figure 3. Distribution of the main clusters of trees in relation to spatial variation in the sand fraction

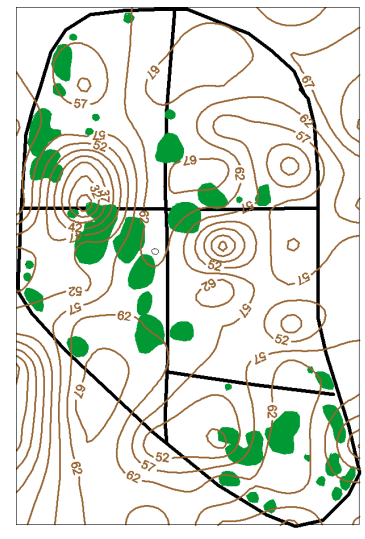

2003

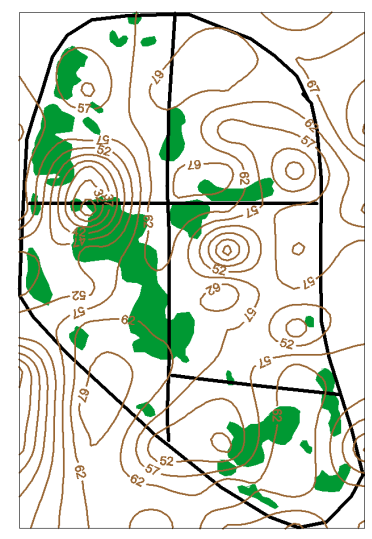

2015
Figure 5. Distribution of the main clusters of trees in relation to spatial variation in the clay fraction

shape and traces of damage, and young individuals often occurred in large numbers in the tree patches.

Black locust is often used in reclamation of degraded land in Poland and all over Europe, mainly because it is a habitat-forming species. It is able to fix atmospheric nitrogen with bacteria of the genus Rhizobium [e.g. Mazurek 2015], at a rate varying widely from 23 to $300 \mathrm{~kg} \mathrm{ha}^{-1}$ year $^{-1}$ [Ciejracks et al. 2013]. This results in the production of nitrogen-rich plant litter, especially leaves, whose rapid decay is the main source of organic matter (an increase in organic carbon) and availability of nitrogen for other plants [Rahmonov and Parusel 2012, Ciejracks et al. 2013; Mazurek 2015]. Black locust also modifies other habitat factors. It has been shown to raise $\mathrm{pH}$ due to the calcium and magnesium ions contained in its leaves, and to increase the content of available phosphorus and the proportion of alkali cations in the soil adsorption complex [vide Mazurek 2015]. 
This tree is considered a highly invasive species. In the area covered by the study the black locust trees usually formed dense clusters in which the share of this species exceeded $90 \%$. Forming dense stands, the black locust shades the surface, leading to elimination of light-demanding species. This results in floristic impoverishment in the herbaceous layer under the canopy in thickets dominated by this species [Rahmonov and Parusel 2012]. There is, however a marked increase in the proportion of nitrophilous and ruderal species in the herbaceous layer [Dzwonko and Loster 1997]. For this reason Rahmonov and Parusel [2012] point out that the effects of the development of black locust monocultures are not straightforward, and planning of the reclamation process should take into account the considerable decrease in the biodiversity of areas colonized by black locust, resulting from its allelopathic properties.

The species with the second highest share of the tree stand growing on the reclaimed soda waste dumps, at $10 \%$, is European aspen (Populus tremula). This species grows to an average height of $12.2 \mathrm{~m}$ in the study area and attains an average diameter at breast height of $19.9 \mathrm{~cm}$ (Table 2). Aspen grows best on well-drained clay soil rich in organic matter, calcium, magnesium, potassium and nitrogen. It is, however, a species with considerable soil tolerance and can survive on both shallow sands and heavy clay soils. As in the case of black locust, it is a typical pioneer species characterized by both generative and vegetative propagation. Vegetative propagation takes place through the formation of root suckers from lateral buds on small lateral roots $(0.5-2.5 \mathrm{~cm}$ in diameter). Their production is stimulated by various disturbances, such as felling, fire, wind breakage or defoliation. Most root suckers develop up to $20 \mathrm{~m}$ from the parent tree, but this distance can reach 30-40 m [MacKenzie 2010].

Silver birch on the reclaimed soda waste dumps accounts for only 5\% of the stand. Its average height and diameter at breast height are $12.6 \mathrm{~m}$ and $18.1 \mathrm{~cm}$, respectively (Table 2). Birch is a light-demending pioneer species appearing in the early successional stage. It quickly colonizes the terrain owing to abundant production of winged seeds and rapid growth at a young age. It finds the best conditions for development on fairly fertile, light, permeable soils, preferably with acidic pH [Hynynen et al. 2009, Beck et al. 2016]. It has lower tolerance for compact or wet soils. As reported by Prach and Pyšek [1994], silver birch is a species that clearly dominates on spontaneously overgrown abandoned and degraded land. Despite its high tolerance for habitat conditions, it is not considered a valuable species improving habitat quality.

Goat willow, with a much smaller share in the study area (1\%), and elder (Sambucus nigra), often found in the undergrowth on soda waste dumps, according to Prach and Pyšek [1994] are the most frequent colonizers of unused land in urbanized areas of Central Europe.

The basis for successful reclamation is a thorough examination of the initial conditions and determination of the function and target structure of the ecosystem to be created. There are several ways to create new ecosystems on reclaimed land. The simplest and least expensive approach, but often taking a long time, is to leave the area to natural processes of succession with no interference. The second approach is of a technical nature and involves modification of abiotic and biotic habitat factors and the introduction of the desired plant species. An intermediate approach involves aiding natural succession by modifying abiotic and biotic factors, but to a limited extent, and then enabling spontaneous succession of vegetation while maintaining control of its progress [Prach et al. 2007].

The course of action taken to reclaim the Solvay soda waste dumps most resembles the last of these models, but this was not intended. The target conception for management of this area was to create park area but only basic reclamation procedures were carried out. The main objective in this case was to revegetate the area and make it less of a nuisance, whereas the woody vegetation appeared spontaneously. A limited number of tree species was maintained here, having appeared in the first phase of colonization of the reclaimed dumps. As compared to 2003, no new patches of trees are observed but only expansion of the old ones (Figures 2-5). The area of the main patches, determined on the basis of aerial photographs, grew from $6,235.2 \mathrm{~m}^{2}$ in 2003 to $18,682.9 \mathrm{~m}^{2}$ in 2015 , a $66.6 \%$ increase in a 12 -year period.

The fact that new individuals have not appeared is due to the development of dense herbaceous vegetation, initially from species that were sown, with a large share of yellow melilot (Melilotus officinalis) and white melilot (Melilotus alba), and in the later stage with dominance of the herbaceous layer by highly expansive species 
such as wood small-reed (Calamagrostis epigejos) and quack grass (Elymus repens). Competition from herbaceous vegetation impedes the germination and development of tree seedlings with light seeds [Prach 2003], whereas root suckers have a chance to force their way through the vegetation cover and necromass [Frączek 2007], which is particularly important where there is no mowing. Fires observed in this area were an additional factor limiting the appearance of seedlings and stimulating vegetative propagation of trees.

The properties of the mineral cover applied in reclamation of the soda waste dumps have a greater impact on differentiation of the development of the herbaceous vegetation [Zając and Zarzycki 2012] than in the case of the tree stand. The distribution of thickness and the granulometric composition of the mineral cover were not found to be closely linked to the distribution of clusters of trees (Figures 2-5). They do not occur in the zone with the thickest mineral cover, but their distribution is clearly linked to the former inner embankments separating individual settling ponds mainly consisting of slag [Pałka and Sanecki 1992] which tops of were levelled during the reclamation process.

An admixture of coarse-grained material may thus be a factor facilitating the development of the root system of trees, as confirmed by the considerably superior development of woody vegetation on the outer embankments composed of the same material. Signs of gleying are visible in the loamy soil cover, which is indicative of unfavourable air and water conditions in this layer, while deeper development of root systems lessens the chemical properties of soda waste-high salinity and alkaline pH [Boroń et al. 2000, Zając et al. 2007]. Variation in moisture levels in the mineral cover is also reflected in the species composition of herbaceous vegetation, which includes species typical of dry habitats as well as species typical of wet habitats [Zając and Zarzycki 2012], which should be linked to the fine-textured mineral cover and the resulting water stagnation during wet periods and parching during dry periods [Ewing 2002].

The thickness of the soil cover used in reclamation of waste deposit sites, which is to form a substrate for the development of vegetation, should depend mainly on the type of soil, the level of summer rainfall and the tree species selected [Dobson and Moffat 1993], and should correspond to the extent of the root zone [Gworek et al. 2004]. It should be tailored to the type of land use planned. Building Research Institute guidelines [Wysociński 2009] for sealing surface landfills recommend the following minimum thicknesses for this layer: 1.2 to $1.8 \mathrm{~m}$ for areas to be covered with trees (optimally $1.5 \mathrm{~m}$ subsoil and $0.3 \mathrm{~m}$ topsoil), from 0.6 to $1.0 \mathrm{~m}$ for shrubs, and $0.5 \mathrm{~m}$ for lawns.

In the case of the complex of soda waste dumps analysed in this study, the thickness of the mineral cover used for reclamation is sufficient for the development of herbaceous vegetation, but is not a factor differentiating the distribution and development of spontaneous woody vegetation. It is, however, shallow enough $(75 \%$ of the surface is covered by a layer 10-30 cm deep [Zając 2009]) that it may limit the appearance of more demanding tree species and halt the succession at the level of pioneer species. It may also be a limitation for the further development and stable establishment of existing trees in the substrate as they grow, as their roots are generally very shallow.

Analysis of several dozen successional series in different types of anthropogenically degraded habitats has shown that in some areas trees did not appear even for 30 years, while in other successional series woody plants appeared before the eighth year of succession, and after 20 years has reached their maximum area cover, which later changed very slowly [Prach and Pysek 1994]. The development of woody vegetation proved best in moderate environmental conditions and was delayed in extreme [Prach and Pysek 2007, Prach 2003]. In the case of the dumps in the present study, whose reclamation was completed in 1995 , the rate of changes in area cover by the tree stand may thus be expected to slow down.

The pioneer species occurring here often take part in the initial stages of succession on degraded and abandoned land. This is possible due to their ecological properties, particularly wide tolerance for habitat conditions, abundant fruit production, anemochoria, a tendency towards vegetative propagation, high light demands, and rapid growth at a young age [Frączek 2007]. According to Bradshaw [1996], in biological reclamation it is most important to appropriately direct the succession of vegetation and then leave the area to natural processes. This may involve the need for suitable planting, but to achieve satisfactory development of the plants we must ensure that the substrate is of good quality or can be improved by appropriate procedures.

In view of the intended use of the 'White Seas' as urban green spaces, in accordance with 
the area development plan, should further reclamation procedures be carried out to improve the quality of the substrate and enrich the species composition of the tree stand, or should further management of the area consist in maintaining its current state? It seems that in the current situation the second model is more justified, both economically and ecologically.

The first variant entails substantial financial expenditures, while the most important challenge in the second, inexpensive variant will be to control the spread of the invasive black locust. One promising method is partial removal of bark in a strip from the perimeter of the tree, which prevents regrowth of the plant from its base and thus leads to its death [Böcker and Dirk 2008 as cited in Cierjacks et al. 2013].

\section{CONCLUSIONS}

1. The substantial spatial variation in the parameters analysed and the fine-textured mineral material used in reclamation of the soda waste dumps of the former Krakow Soda Plant Solvay indicate that this material did not fully succeed in improving conditions for the development and growth of trees. No connection was found between the analysed parameters of the mineral cover (thickness and granulometric composition) and the distribution and development of spontaneous woody vegetation.

2. The species composition of the woody vegetation is limited, and dominated by pioneer species, mainly the expansive black locust (Robinia pseudoacacia). The last 12 years have seen no new clusters of trees but only the expansion of old ones, whose area increased by $66.6 \%$ during this period.

3. The appearance of new individuals is mainly limited by competition from dense herbaceous vegetation. Trees capable of vegetative propagation, additionally stimulated by various types of disturbances (fires or mechanical damage) are dominant.

4. To carry out the plan to use the area of the soda waste deposit dumps of the former Krakow Soda Plant Solvay as urban green spaces, the question of the target ecosystem structure must be considered and then a suitable model of action should be chosen: further reclamation procedures improving the quality of the substrate and enrich- ing the species composition of the tree stand, or management based on the current state, together with control of the course of natural selection of vegetation, particularly the spread of invasive species (black locust). It seems that in the current situation the second model is more justified, both economically and ecologically.

\section{Acknowledgements}

The research was realised within the Projects No. DS-3337 and DS-3331, financed from the reaserch grant allocated by the Ministry of Science and Higher Education.

\section{REFERENCES}

1. Beck, P., Caudullo, G., de Rigo, D., Tinner, W., 2016. Betula pendula, Betula pubescens and other birches in Europe: distribution, habitat, usage and threats. In: San-Miguel-Ayanz, J., de Rigo, D., Caudullo, G., Houston Durrant, T., Mauri, A. (Eds.), European Atlas of Forest Tree Species. Publ. Off. EU, Luxembourg. 70-73.

2. Boroń K., Zając E., Klatka S. 2000. Rekultywacja terenów składowania odpadów KZS „Solvay” w Krakowie. Inż. Ekol. 1, 58-64.

3. Bradshaw A.D. 1996. Underlying principles of restoration. Can. J. Fish. Aquat. Sci. 53 (Suppl. 1), 3-9.

4. Cierjacks A., Kowarik I., Joshi J., Hempel S., Ristow M., von der Lippe M. Weber E. 2013. Biological Flora of the British Isles: Robinia pseudoacacia. J. Ecol. 101, 1623-1640.

5. Dobson M.C., Moffat A.J. 1993. The potential for woodland establishment on landfill sites. Department of the Environment, HMSO, London.

6. Dyguś K. H., Sienkiewicz J. 2014. Roślinność na składowisku odpadów posodowych w Janikowie po 13 latach rekultywacji. Inż. Ekol. 36, 65-97.

7. Dzwonko Z., Loster S. 1997. Effects of dominant trees and anthropogenic disturbances on species richness and floristic composition of secondary communities in southern Poland. J. Appl. Ecol. 34, 861-870.

8. Ewing K. 2002. Mounding as a technique for restoration of Prairie on a capped landfill in the Puget Sound Lowlands. Rest. Ecol. 10, 289-296.

9. Frączek M. 2007. Rola rozmnażania wegetatywnego osiki Populus tremula L. W procesie zarastania nieużytkowanych polan. Stud. Naturae. 54, I, 47-59.

10. Gworek B., Barański A., Kondzielski I., Kucharski R., Sas-Nowosielska A., Małkowski E., Nogaj K., Rzychoń D., Worsztynowicz A. 2004. Technologie rekultywacji gleb. Instytut Ochrony Środowiska, Warszawa. 
11. Hellwig Z. 1993. Elementy rachunku prawdopodobieństwa i statystyki matematycznej. Wydawnictwo Naukowe PWN. Warszawa.

12. Hynynen J., Niemistö P., Viherä-Aarnio A., Brunner A., Hein S., Velling P. 2010. Silviculture of birch (Betula pendula Roth and Betula pubescens Ehrh.) in northern Europe. Forestry. 83, 1, 103-119.

13. Klasyfikacja uziarnienia gleb i utworów mineralnych - PTG 2008. Uchwała Zarządu Głównego Polskiego Towarzystwa Gleboznawczego z dnia 5 marca 2008.

14. Klatka S., Boroń K., Ryczek M. 2005. Obszarowa zmienność wybranych właściwości gleby użytej do rekultywacji osadników byłych Krakowskich Zakładów Sodowych Solvay. Obieg pierwiastków w przyrodzie. Monografia. Tom III. Instytut Ochrony Środowiska Warszawa. 711-715.

15. Klatka S. 2009. Analiza zmienności przestrzennej składu granulometrycznego nadkładu mineralnego na zrekultywowanym osadniku posodowym w Krakowie z wykorzystaniem metody krigingu. Ochr. Środ. Zasobów Nat. 38, 131-139.

16. MacKenzie N.A. 2010. Ecology, conservation and management of Aspen. A Literature Review. Scottish Native Woods (Aberfeldy).

17. Małecki Z. 1997. Restrukturyzacja- likwidacja-zagospodarowanie KZS Solvay. In: Problemy Sozologiczne Aglomeracji Miejsko-Przemysłowych. Komitet Inżynierii Środowiska PAN Kraków.

18. Marx D.B, Thompson K.C. 1987. Practical aspect of agricultural Kriging. Arkansas Agricultural Experiment Station Bulletin.

19. Mazurek R. 2015. Przestrzenne zróżnicowanie właściwości gleb uprawnych sąsiadujących $\mathrm{Z}$ zadrzewieniami złożonymi $\mathrm{z}$ robinii akacjowej (Robinia pseudoacacia) i olszy czarnej (Alnus glutinosa). Zesz. Nauk. Uniwersytetu Rolniczego w Krakowie ser. Rozprawy, 526, 403.

20. Nagawiecka H., Boroń, K., Gałka A., Lipka K., Turschmid M. 1975-1977. Studium możliwości zagospodarowania poeksploatacyjnego osadników odpadów posodowych w Krakowskich Zakładach Sodowych. Instytut Melioracji Rolnych i Leśnych Akademii Rolniczej w Krakowie (Msc.).

21. Pałka J., Sanecki L. 1992. Krakowskie Zakłady Sodowe „Solvay”. Raport o stanie istniejącym. DDJM - Biuro Architektoniczne, Kraków.

22. Prach K., Pyšek P. 1994. Spontaneous establishment of woody plants in Central European derelict sites and their potential for restoration. Rest. Ecol. 2, 3, 190-197.

23. Prach K. 2003. Spontaneous succession in CentralEuropean man-made habitats: What information can be used in restoration practice? Appl. Veg. Sci. 6, 125-129.
24. Prach K., Marrs R., Pyšek P., van Diggelen R. 2007. Manipulation of succession. In: Linking restoration and ecological succession. L.R. Walker J. Walker, R. J. Hobbs (eds.). Springer. 121-149.

25. Rahmonov O., Parusel T., 2012, Wpływ opadu roślinnego robinii akacjowej Robinia pseudoacacia L. na proces rozwoju gleby na obszarach zdegradowanych, Studia i Materiały Centrum Edukacji Przyrodniczo-Leśnej. 33, 4, 81-92.

26. Siuta J., Sienkiewicz R. 2001: Rekultywacja terenu składowania odpadów posodowych w Janikowie. Inż. Ekol. 3: 43-59.

27. Siuta J. 2014. Rekultywacyjna efektywność osadów ściekowych na składowisku odpadów posodowych w Janikowie. Inż. Ekol. 36, 98-119

28. Siuta J., Sienkiewicz J. 2014. Chemizm roślin i zrekultywowanego gruntu na składowisku odpadów posodowych w Janikowie. Inż. Ekol. 38, 70-90.

29. Trzcińska-Tacik H. 1966. Flora i roślinność zwałów Krakowskich Zakładów Sodowych. Fragm. Flor. Geobot. 12, 3, 243-307.

30. Trzcińska-Tacik H. 1993. Szata roślinna Krakowskich Zakładów Sodowych w kontekście ich rekultywacji. In: Sozologia na obszarze antropopresji - przykład Krakowa. Red. A. Paulo. Przewodnik III Konferencji Sozologicznej. PTG, AGH Kraków, 87-89.

31. Uchwała NR LVIII/777/12 Rady Miasta Krakowa z dnia 10 października 2012 r. w sprawie uchwalenia miejscowego planu zagospodarowania przestrzennego obszaru „Białe Morza”. Dziennik Urzędowy Województwa Małopolskiego z dnia 23 października 2012 r. poz. 5214.

32. Urbańska J. Urbański K. 2012. Selected aspects of reclamation of soda waste landfill sites. Geomatics and Environmental Engineering. 6, 4, 83-90.

33. Wysociński L. 2009. Zasady budowy składowisk odpadów. Instytut Techniki Budowlanej. Instrukcje, Wytyczne, Poradniki. 444. Warszawa.

34. Zarzycki J., Zając E. 2001. Badania roślinności i podłoża na niezrekultywowanym osadniku byłych Krakowskich Zakładów Sodowych „Solvay”. Zesz. Nauk. AR w Krakowie. 390, 22, 37-46.

35. Zając E., Klatka S., Ryczek M. 2007. Wpływ nadkładu glebowego na zmiany odczynu i przewodnictwa elektrolitycznego odpadów posodowych w warunkach doświadczenia modelowego. Zesz. Probl. Post. Nauk Rol. PAN, Warszawa, 520, I, 213-219.

36. Zając E. 2009. Analiza właściwości fizycznych i chemicznych warstwy izolacyjnej na zrekultywowanych osadnikach posodowych byłych KZS Solvay. Ochr. Śr. Zasobów Nat. 38, 388-395.

37. Zając E., Zarzycki J. 2012 Revegetation of reclaimed soda waste dumps: effects of topsoil parameters. J. Elem. 17, 3, 525-536. 